Nutr. Dieta 1968;10:I-IV

\title{
Contents, Vol. 10, 1968
}

\section{Nutritio et Dieta}

Europäische Zeitschrift für Ernährung und Diätetik

European Journal of Nutrition and Dietetics

Journal européen de nutrition et de diététique

\section{Editores}

G. Ågren, Uppsala

R. Ammon, Homburg/Saar

E. J. Bigwood, Bruxelles

R. Bolleh, Wien

B. Borgström, Lund

E. Le Breton, Paris

M. Coppo, Modena

H. D. Cremer, Giessen Ch. Darnaud, Toulouse M. Demole, Geneve M. J. L. Dols, Wassenaar N. Eeg-Larsen, Oslo

F. $\quad$ Tidanza, Perugia

H. Glatzel, Dortmund

W. Gloor-Meyer, Zurich

J. Gontzea, Bucarest

H. Gounelle, Paris

J. J. Groen, Jerusalem

W. Halden, Graz

C. Den Hartog, Den Haag

E. HOFF-JøRGENSEN,

København B. Isaksson, Göteborg R. Jacquot, Paris H. Kraut, Dortmund J. Kühnau, Hamburg J.

Lederer, Louvain

F. Mancini, Roma

G. A. Martini, Marburg/Lahn

O. Mellander, Göteborg

H. G. Mogena, Madrid H. Mohler, Zurich A. Mosse, Paris R. Nicolaysen, Oslo

G. Péquignot, Paris

F. A. Pezold, Berlin

P. Roine, Helsinki

H. Sarles, Marseille

T. F. S. M. Van Schaik, Den Haag

G. S. Schettler, Berlin

J. C. Somogyi, Zurich

H. J. Thomasson, Vlaardingen

F. J. Traissac, Bordeaux

L. Travia, Roma 
G. P. Vecchi, Modena

G. Verdonk, Gand

F. Verzár, Basel

R. Wenger, Wien J. F. De Wijn, Zeist J. Yudkin, London

Redactores

E. Azérad, Paris

H. Kapp, Basel

J. Trémolières, Paris

K. A. J. Wretlind,

Stockholm N. Zöixner, München

1968

Vol. 10

BASEL (Schweiz) S. KARGER NEW YORK

INDEX

Ahlström, A.; Koivistoinen, P.; Saloniemi, Riitta and Salo, Paula: Bioevaluation

of Dietary Iron in Growing Rats. II. Relationship between the Iron Level in a Semolina

Diet and the Response of Growing Rats. - Beivertung des Nahrungseisens bei wachsenden

Ratten. II. Bezíehung zwischen Eisengehalt einer Mehldiät und der Wirkung bei der wachsenden Ratte. - Evaluation biologique du fer dans Talimentation chez les rats en croissance. II. Relation entre la teneur en fer dans un regime à la semoule et la réponse des rats en croissance 254

Ahlström, A.: vide Koivistoinen, P.

Azouaou, G.: vide Debry, G.

Babala, J. and Ginter, E.: Coronary Changes Experimentally Produced in Guinea-Pigs. -

Durch Hypercholesterínämíe experimentell erzeugte Veränderungen der Koronargefässe beím Meerschwein. - Modifications expérimentelles des coronaires produites par une hypercholesterolémie chez le cobaye 133

Babala, J.: vide Bucko, A.

Barnes, R. H.: The Inseparability of Nutrition from the Social and the Biological

Sciences. - Die Untrennbarkeit der Ernährung von den sozialen und den biologíschen Wissenschaften. - De la nécessaire association de la nutrition aux sciences sociales et biologiques

Baron, P. et Trémolières, J.: Influence de l'éthanol administré à dose toxique sur les échanges respiratoires du rat. - Influence of Ethyl Alcohol in Toxic Dosage on Respiratory Balance in the Rat. - Wirkung toxischer Aethanoldosen auf den respiratorischen Gasaustausch 229

Blumberger, W. and Glatzel, H.: Conditioned Salivary Response and its Significance. Der bedíngte Speíchel-Sekretions-Reflex und seine Bedeutung. - Réponse salivaire conditionnée et sa signification 123

Braekkan, 0. R.; Lambertsen, G.; Utne, F. and Njaa, L. R.: Hydrogenated Marine Fat, its Influence on the Fatty Acid Composition on Depot Fats and Liver Lipids in the Rat. - Hydrogenisierte marine Fette, ihre Wirkung auf den Fettsäuregehalt der Depotund Leberfette der Ratte. - Une graisse de poissons marine hydrogénée, son influence sur la composition en acides gras des depots lipidiques et sur les lipides hépatiques du rat . . 24 Braun, T.: vide Fabry, P. 
Brodan, V.; Kuhn, E.; Rath, R. and Masék, J.: Influence of Acute Fasting and Refeeding on Glucose Utilization in Healthy Women. - Der Einfluss akuten Fastens und Wiederaufnahme der Ernährung auf die Glukoseverwertung bei gesunden Frauen. - In fluence d'un jeûne severe suivi d'une réalimentation sur Tutilisation du glucose chez la femme en bonne santé 108

Bucko, A.; Kopec, Z. and Babala, J.: Effect of Starvation on the Function and Morpho logy of Rat Pancreas. - Wirkung des Hungers auf Funktíon und Morphologie des Rattenpankreas. - Influence du jeûne sur le fonctionnement et la morphologie du pancreas du rat 266

Bucko, A. and Kopec, Z.: Adaptation of Enzymes Activity of the Rat Pancreas on Altered Food Intake. - Adaptation der Enzymaktivítät des Rattenpankreas an Anderungen der Nahrungszufuhr. - Adaptation des activités enzymatiques du pancreas de rat aux changements de regime alimentaire 276

Burckhart, 0.: vide Günther, F.

Chauhan, Sushila and Doniach, I.: Effect of Ethanol Consumption on Growth Rate in

Adult Rats. - Wirkung der Ãthanolzufuhr auf das Wachstum von Ratten. - Effet de la consommation d'éthanol sur la vitesse de croissance du rat adulte 91

Debry, G.; Rohr, R.; Azouaou, G.; Vassilitch, I. and Mottaz, G.: Etude de Tinfluence du fractionnement de Tapport calorique quotidien en 7 repas sur la chute pondérale des obèses. Study of the Effect of Dividing the Daily Calorie Intake into Seven Meals on Weight Loss in Obese Subjects. - Untersuchung über die Wirkung der Fraktionierung der Nahrungszufuhr in 7 Mahlzeiten auf die Gewichtsabnahme von Fettsüchtigen .... 288

Doniach, I.: vide Chauhan, Sushila.

Fauchet, M.; Marnay-Gulat, C. et Gounelle, H.: Effet des radiations ionisantes sur la vitamine $\mathrm{K}$ en solution pure. - Effect of Ionizing Radiations on Vitamin K in Pure Solu tion. - Wirkung ionisierender Strahlen auf Vitamin K in reiner Lösung 143

Fábry, P.; Poledne, R.; Kazdová, L. and Braun, T.: The Effect of Feeding Frequency and Type of Dietary Carbohydrate on Hepatic Lipogenesis in the Albino Rat. -

Wirkung der Fütterungsfrequenz und der Art der Kohlenhydrate auf die Fettsynthese der Leber beí Albínoraten. - Effet de la frequence d'absorption de la nourriture et du type d'hydrate de carbone du regime sur la lipogénèse chez le rat albinos

Ginter, E.: vide Babala, J.

Glatzel, H. and Rüberg-Schweer, M.: Regional Influence on Cutaneous Blood Flow Effected by Oral Spice Intake. - Regionale Beeinflussung der Hautdurchblutung durch perorale Xufuhr von Gewiirzen. - Influence locale de Гingestion d'épices sur Tirrigation sanguine cutanée 194

Glatzel, H.: vide Blumberger, W.

Gounelle, H.: vide Fauchet, M.

Groen, J. J.: The Indirect Method for the Approximate Estimation of the Caloric Ex penditure on Physical Activity, for Use in Dietary Surveys. - Indírekte Methode zur Schätzung des Kalorienverbrauches beí körperlicher Arbeit zur Beurteílung der Ernährung. - La méthode indirecte pour estimer approximativement la dépense calorique de Tactivité physique, en vue des enquêtes alimentaires 9

Guggenheim, K.: vide Pongpaew, Pranet. 
Günther, F.; Burckhart, 0. und Oostinga, I.: Zur Kenntnis desMineralstoffgehaltes der Gewürze. - Information on Mineral Contents of Spices. - Pour la connaissance de la teneur en minéraux des épices

151

HÅKANSSON, I.: Experience in Long-Term Studies on Nine Intravenous Fat Emulsions in Dogs. - Erfahrungen bei Langzeítuntersuchungen an Hunden mit neun Fettemulsíonen zur intravenösen Infusion. - Etude expérimentale à long terme d'injections intraveineuses de neuf emulsions graisseuses sur le chien 54

Jager, F. C.: Determination of Vitamin E Requirement in Rats by Means of Spontaneous Haemolysis in. vitro. - Bestímmung des Vitamin-E-Bedarfs der Ratte durch Spontanhämolyse in vitro. - Determination du besoin en vitamine $\mathrm{E}$ chez le rat au moyen de Thémolyse spontanée in vitro 215

Jäppinen, Tuula! vide Koivistoinen, P.

Kazdová, L.: vide Fabry, P.

Koivistoinen, P.; Ahlström, A. and Jäppinen, Tuula: Bioevaluation of Dietary Iron in Growing Rats. I. Relationship between the Iron Level in a Milk Powder Diet and the Response of Growing Rats. - Bewertung des Nahrungseísens beí wachsenden Ratten. I. Beziehung zwischen Eisengehalt einer Milchpulverkost und der Wirkung auf wachsende Ratten. - Evaluation biologique du fer dans le regime chez les rats en croissance. I. Relation entre la teneur en fer d'un regime au lait en poudre et la réponse des rats en croissance 241

Koivistoinen, P.: vide Ahlström, A.

Kopec, Z.: vide Bucko, A.

Kraut, H. und Rolle, I.: Vitamin-Bj- und -B2-Gehalt der Grünalge Scenedesmus obliquus. Amounts of Vitamins Bx and B2 Present in the Green Alga Scenedesmus obliquus. - Teneur en vitamine Bx et B2 de $\Gamma$ algue verte Scenedesmus obliquus .... 183

Kuhn, E.: vide Brodan, V.

Kurkela, Rakel: vide Uksila, E.

Lambertsen, G.: vide Braekkan, 0. R.

Marnay-Gulat, C: vide Fauchet, $\mathrm{M}$.

Masèk, J.: vide Brodan, V.

Mottaz, G.: vide Debry, G.

Njaa, L. R.: vide Braekkan, 0. R.

Oostinga, I.: vide Günther, F.

Ottani, V.: vide Turchetto, Ed.

Poledne, R.: vide Fabry, P.

Pongpaew, Praneet and Guggenheim, K.: The Nutritional Availability of Tryptophan in

Foods. - Verwertbarkeit von Tryptophan in Nahrungsmítteln. - Valeur nutritive du tryptophane dans les aliments 297

Rath, R.: vide Brodan, V.

Rohr, R.: vide Debry, G.

Rolle, I.: vide Kraut, $\mathrm{H}$.

Salo, Paula: vide Ahlström, A.

Rüberg-Schweer, M.: vide Glatzel, H.

Saloniemi, Riitta: vide Ahlström, A.

Tacconi, Mariateresa: vide Zöllner, N. 
Trautner, K.: Weitere Untersuchungen über die Biosynthese von Vitamin C in Kartoffelscheiben. - Further Investigation into the Biosynthesis of Vitamin C in Potato Slices. - Nouvelles recherches sur la biosynthese de la vitamine $\mathrm{C}$ dans des couches de pommes de terre 100

Trémolières, J.: vide Baron, $\mathrm{P}$.

Turchetto, Ed.; Ottani, V.; Zanetti, P. and Weiss, K.: Hepatic Acids after Ethanol Ingestion. - Leberfettsäuren nach Einnahme von Alkohol. - Acides gras hépatiques après une ingestion d'éthanol 224

Uksila, E. and Kurkela, Rakel: Evaluation of the Nutritional Properties of some Heated Fats by Animal Experiments. - Bestímmung des Nährwertes erhitzter Fette im Tíerversuch. - Estimation des propriétés nutritives de quelques graisses chauffées par des experiences sur $\Gamma$ animal 45

Utne, F.: vide Braekkan, 0. R.

Vassilitch, I.: vide Debry, G.

Weiss, H.: vide Turchetto, Ed.

Wijn, de F. J. and Zaat, J. C. A.: Appropriate Body Weight for Height and Skeletal Frame of Adolescents and Young Adults. - Angemessenes Kòrpergewícht in bezug auf Länge und Knochenbau beí Jugendlichen und jungen Erwachsenen. - Poids corporel approprié pour une taille et une morphologie du squelette données d'adolescents et de jeunes adultes 161

Zaat, J. C. A.: vide Wijn, de F. J.

Zanetti, P.: vide Turchetto, Ed.

Zöllner, N. and Tacconi, Mariateresa: Effect of High Fat Diet on Serum Lipids of Miniature Pigs. - Wirkung eíner stark fetthaltígen Kost auf die Serumlípide des Zwergschweínes. - Effet d'un regime riche en graisse sur les lipides sériques des pores minia tures $\quad 16$

All rights, including that of translation into other languages, reserved. Photomechanic reproduction (photocopy, microcopy) of this volume or parts

thereof without special permission of the publishers is prohibited

(C)

Copyright 1968 by S. Karger AG, Basel

Printed in Switzerland by Lüdin AG, Liestal

Cliches: Aberegg-Steiner \& Cie., AG 